Available online on 15.09.2020 at http://jddtonline.info
Open Access to Pharmaceutical and Medical Research
unrestricted non-commercial use, provided the open Access article which permits

Open $\odot$ Access

Research Article

\title{
New Analytical Method Development and Validation for Simultaneous Estimation of Sofosbuvir and Velpatasvir in Bulk and Pharmaceutical Dosage Form by RP-HPLC Method
}

\author{
T. Hanuman ${ }^{1 *}$, T. Sivakkumar' ${ }^{2}$ S. Sridhar ${ }^{1}$ \\ 1 Department of Pharmaceutical Analysis, Malla Reddy College of Pharmacy, Secunderabad. Telangana, India \\ ${ }^{2}$ Department of Pharmaceutical Chemistry, Annamalai University, Chidambaram, Tamil Nadu, India
}

\begin{abstract}
A simple, specific and accurate reverse phase high performance liquid chromatographic method was developed for the simultaneous determination Sofosbuvir and Velpatasvirin pharmaceutical dosage form. The column used was $\mathrm{Kromosil}_{18}(150 \mathrm{~mm} \mathrm{x} 4.6 \mathrm{~mm}$, $5 \mu \mathrm{m}) \mathrm{in}$ isocratic mode, with mobile phase containing phosphate buffer andacetonitrile(70:30v/v). The buffer is prepared by adding 1.41 gm of sodium dihyrogen ortho phosphate in a $1000 \mathrm{ml}$ of volumetric flask add about $900 \mathrm{ml}$ of milli-Q water added and degas to sonicate and finally make up the volume with water then $\mathrm{pH}$ adjusted to 3.5 with dil. orthophosphoric acid solution. The flow rate was $1.0 \mathrm{ml} / \mathrm{min}$ and effluents were monitored at $260 \mathrm{~nm}$. The retention times of Sofosbuvir and Velpatasvirwere found to be $2.404 \mathrm{~min}$ and 2.986 min, respectively. The linearity for Sofosbuvir and Velpatasvirwere in the range of $40-240 \mu \mathrm{g} / \mathrm{ml}$ and $10-60 \mu \mathrm{g} / \mathrm{ml}$ respectively. The recoveries of Sofosbuvir and Velpatasvirwere found to be $99.64 \%$ and $99.25 \%$, respectively. The proposed method was validated and successfully applied to the estimation of Sofosbuvir and Velpatasvirin combined tablet dosage forms.
\end{abstract}

Keywords: Sofosbuvir, Velpatasvir, Validation, Buffer and ICH Guidelines.

Article Info: Received 10 July 2020; Review Completed 23 Aug 2020; Accepted 29 August 2020; Available online 15 September 2020

Cite this article as:

Hanuman T, Sivakkumar T, Sridhar S, New Analytical Method Development and Validation for Simultaneous Estimation of Sofosbuvir and Velpatasvir in Bulk and Pharmaceutical Dosage Form by RP-HPLC Method, Journal of Drug Delivery and Therapeutics. 2020; 10(5):143-148 http://dx.doi.org/10.22270/jddt.v10i5.4296

*Address for Correspondence:

T. Hanuman, Department of Pharmaceutical Analysis, Malla Reddy College of Pharmacy, Secunderabad. Telangana, India

\section{INTRODUCTION}

Chemically, Sofosbuvir is propan-2-yl (2S)-2-\{[(S)$\{[(2 \mathrm{R}, 3 \mathrm{R}, 4 \mathrm{R}, 5 \mathrm{R})-5-(2,4-$ dioxo-1,2,3,4-tetrahydropyrimidin1-yl)-4-fluoro-3-hydroxy-4-methyloxolan-2 yl]methoxy\} (phenoxy)phosphoryl] amino\}propanoate. The chemical formula is $\mathrm{C}_{22} \mathrm{H}_{29} \mathrm{FN}_{3} \mathrm{O}_{9} \mathrm{P}$. The molecular formula is $529.458 \mathrm{~g} / \mathrm{mol}$. Sofosbuvir (tradename Sovaldi) is a direct acting antiviral medication ${ }^{1}$ used as part of combination therapy to treat chronic Hepatitis C, an infectious liver disease caused by infection with Hepatitis C Virus (HCV). HCV is a single-stranded RNA virus that is categorized into nine distinct genotypes, with genotype 1 being the most common in the United States, and affecting $72 \%$ of all chronic HCV patients .

Velpatasvir is chemically, (2S)-2-\{[hydroxy(methoxy) methylidene]amino $\}-1-[(2 S, 5 S)-2-(17-\{2-[(2 S, 4 S)-1-[(2 R)-2-$ \{[hydroxy(methoxy)methylidene]amino\}-2-phenylacetyl]-4(methoxymethyl)pyrrolidin-2-yl]-1H-imidazol-5-yl\}-21-oxa-

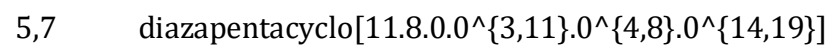
henicosa-1(13),2,4(8),6,9,11,14(19),15,17-nonaen-6-yl)-5methylpyrrolidin-1-yl]-3-methylbutan-1-one. The chemical formula is $\mathrm{C}_{49} \mathrm{H}_{54} \mathrm{~N}_{8} \mathrm{O}_{8}$. The molecular formula is $883.019 \mathrm{~g} / \mathrm{mol}$. Velpatasvir is a Direct-Acting Antiviral (DAA) medication used as part of combination therapy to treat chronic Hepatitis $\mathrm{C}^{2}$, an infectious liver disease caused by infection with Hepatitis C Virus (HCV). HCV is a singlestranded RNA virus that is categorized into nine distinct genotypes, with genotype 1 being the most common in the United States, and affecting $72 \%$ of all chronic HCV patients . Velpatasvir acts as a defective substrate for NS5A (NonStructural Protein 5A), a non-enzymatic viral protein that plays a key role in Hepatitis C Virus replication, assembly, and modulation of host immune responses. 3. Different analytical methods have been reported in the literature for the assay of Sofosbuvir and Velpatasvirin pharmaceuticals and include spectrophotometry, HPLC, UPLC and HPTLC. The present study was to establish a simple, sensitive and 
low cost RP-HPLC method for simultaneous estimation of Sofosbuvir and Velpatasvir in bulk as well as in other dosage forms. The developed method was validated as per ICH guidelines.

\section{MATERIALS AND METHODS}

\section{Materials}

Sofosbuvir and Velpatasvir were kindly supplied by Natco. Acetonitrile, water (HPLC grade, Merck) and all the other reagents of AR grade were purchased from M R Enterprisers. A tablet VELPANAT(NATCO)containing 400mg of Sofosbuvir and $100 \mathrm{mg}$ of Velpatasvir were used.

\section{Instrumentation}

The LC system consisted of a Waters model 515, PDA detector 2998 with $20 \mu \mathrm{L}$ sample loop. The output signals were monitored and integrated using Empower 2 software.

\section{Methods}

\section{Chromatographic conditions}

The elution was isocratic and the mobile phase consisted of a mixture of buffer (accurately weighed 1.41gm of sodium dihyrogen ortho phosphate in a $1000 \mathrm{ml}$ of volumetric flask add about $900 \mathrm{ml}$ of milli-Q water added and degas to sonicate and finally make up the volume with water then $\mathrm{pH}$ adjusted to 3.5 with dil. orthophosphoric acid solution) andacetonitrile (70:30 v/v). The mobile phase was filtered through a $0.45-\mu \mathrm{m}$ (HVLP, Germany) membrane filter prior to use. A Kromosil $\mathrm{C}_{18}(150 \mathrm{~mm} \times 4.6 \mathrm{~mm}, 5 \mu \mathrm{m})$ was used for determination. The flow rate was $1.0 \mathrm{ml} / \mathrm{min}$ and the column was operated at ambient temperature $\left(\sim 30^{\circ} \mathrm{C}\right)$. The volume of sample injected was $10 \mu \mathrm{L}$. Prior to injection of the solutions, column was equilibrated for at least $30 \mathrm{~min}$ with mobile phase flowing through the system. The UV detector was set at wavelength of $260 \mathrm{~nm}$.

\section{Standard Preparation}

Accurately weighed and transferred 40mg of Sofosbuvir and $10 \mathrm{mg}$ of Velpatasvir working Standards into a $100 \mathrm{ml}$ clean dry volumetric flask, add $70 \mathrm{ml}$ of diluent, sonicated for 30 minutes and make up to the final volume with diluent. From the above stock solution, $4 \mathrm{ml}$ was pipetted out in to a $10 \mathrm{ml}$ volumetric flask and then make up to the final volume with diluent. The final concentrations of Sofosbuvir and Velpatasvir are $160 \mu \mathrm{g} / \mathrm{ml}$ and $40 \mu \mathrm{g} / \mathrm{ml}$.

\section{Sample Preparation}

About

20 tablets were taken and their average weight was calculate $\mathrm{d}$. The tablets were crushed to a fine powder and drug equivalent to $40 \mathrm{mg}$ and $10 \mathrm{mg}$ were transferred to a $100 \mathrm{ml}$ volumetric flask, dissolved in diluent. Transfer $4 \mathrm{ml}$ from the above solution into $10 \mathrm{ml}$ volumetric flask and filtered through $0.45 \mu$ membrane filter to get concentration of $160 \mu \mathrm{g} / \mathrm{ml}$ and $40 \mu \mathrm{g} / \mathrm{ml}$ for Sofosbuvir and Velpatasvir.

\section{Method Validation}

The developed method was validated as per ICH guidelines 46 for its accuracy, linearity, precision, specificity, robustness, limit of detection and limit of quantification by using the following procedures.

\section{System suitability}

System suitability and chromatographic parameters were va lidated such as asymmetry factor, tailing factor and number of theoretical plates were calculated.

\section{Linearity}

Linearity of this method was evaluated by linear regression analysis and calculated by least square method and studied by preparing standard solutions of Sofosbuvir and Velpatasvirat different concentration levels. Absorbance of resulting solutions was measured and the calibration curve was plotted between absorbance vs concentration of the drug. The response was found to be linear in the range 40$240 \mu \mathrm{g} / \mathrm{ml} \& 10-60 \mu \mathrm{g} / \mathrm{ml}$ for Sofosbuvir and Velpatasvir.

\section{Accuracy}

Accuracy was performed in triplicatefor various concentrations of Sofosbuvir and Velpatasvir equivalent to $50 \%, 100 \%$ and $150 \%$ of the standard amount were injected into the HPLC system per the test procedure. The average \% recovery was calculated.

\section{Precision}

\section{A) Method Repeatability}

Six sample solutions of the same concentration (100\%) were prepared and injected into the HPLC system as per test procedure.

\section{B) Intermediate Precision (Day to Day variability)}

Two days as per test method conducted the study. For Day-1 and Day-2, six sample solutions of the same concentration $(100 \%)$ were prepared and injected into the HPLC system as per test procedure. As per test method two instruments were checked. The relative standard deviation of the results obtained from different and instruments was less than 2.0.

\section{Limit of detection and Limit of Quantification}

LOD and LOQ were calculated from the average slope and standard deviation from the calibration curve as per ICH guidelines. The LOD and LOQ of Sofosbuvirwere found to be $0.59 \mu \mathrm{g} / \mathrm{ml}$ and $1.80 \mu \mathrm{g} / \mathrm{ml}$ respectively. The LOD and LOQ of Velpatasvir were found to be $0.29 \mu \mathrm{g} / \mathrm{ml}$ and $0.89 \mu \mathrm{g} / \mathrm{ml}$ respectively.

\section{Robustness}

Robustness was done by small deliberate changes in the chromatographic conditions and retention time of Sofosbuvir and Velpatasvir were noted. The factors selected were flow rate and variation in the mobile phase composition.

\section{Assay}

The assay and \% purity were calculated for brand VELPANAT (Natco)with label claim $400 \mathrm{mg}$ and 100mg. The observed value was compared with that of standard value without interference from the excipients used in the tablet dosage form.

\section{RESULTS AND DISCUSSION}

A reverse-phase column procedure was proposed as a suitable method for the simultaneous estimation of Sofosbuvir and Velpatasvirdosage form. The chromatographic conditions were optimized by changing the mobile phase composition. Different ratios were experimented to optimize the mobile phase. Finally, buffer and acetonitrilein the ratio $70: 30 \mathrm{v} / \mathrm{v}$ was used as mobile phase, which showed good resolution of Sofosbuvir and Velpatasvirpeak. The wavelength of detection selected was $260 \mathrm{~nm}$, as the drug showed optimized absorbance at this wavelength. By our proposed method the retention time of Sofosbuvir and Velpatasvir were about $2.404 \mathrm{mins}$ and 
2.986mins and none of the impurities were interfering in its assay. The chromatogram of the drugs is shown in Fig. 1. Calibration curve of Sofosbuvir is shown in Fig. 2 and for
Velpatasvir is in Fig.3. The observed peak area values for respective concentrations are shown in Table 1.

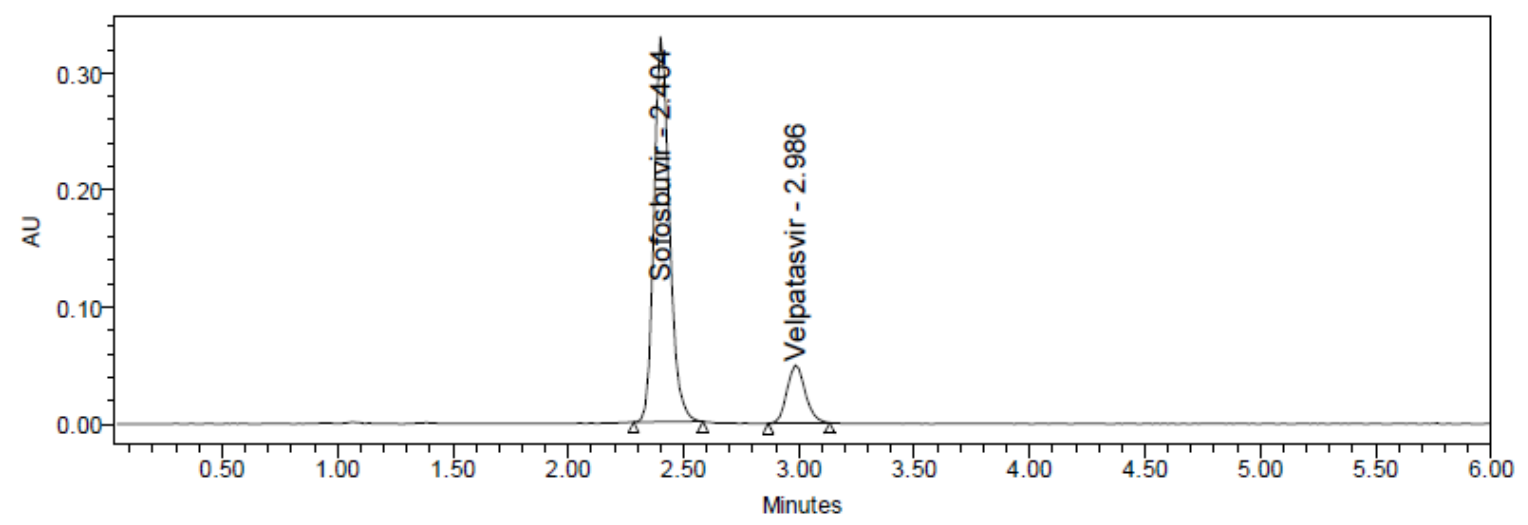

Figure 1: HPLC chromatogram of Sofosbuvir and Velpatasvirin optimized chromatographic conditions

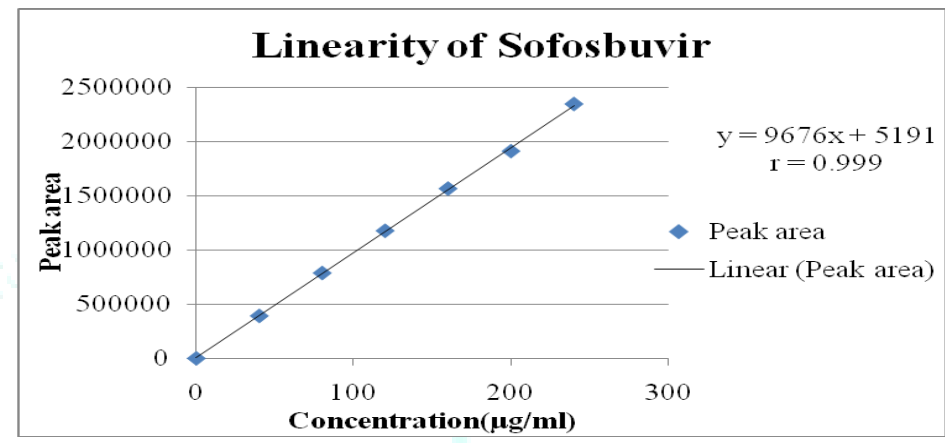

Figure2: Calibration curve of Sofosbuvir in the range 40 to $240 \mu \mathrm{g} / \mathrm{ml}$.

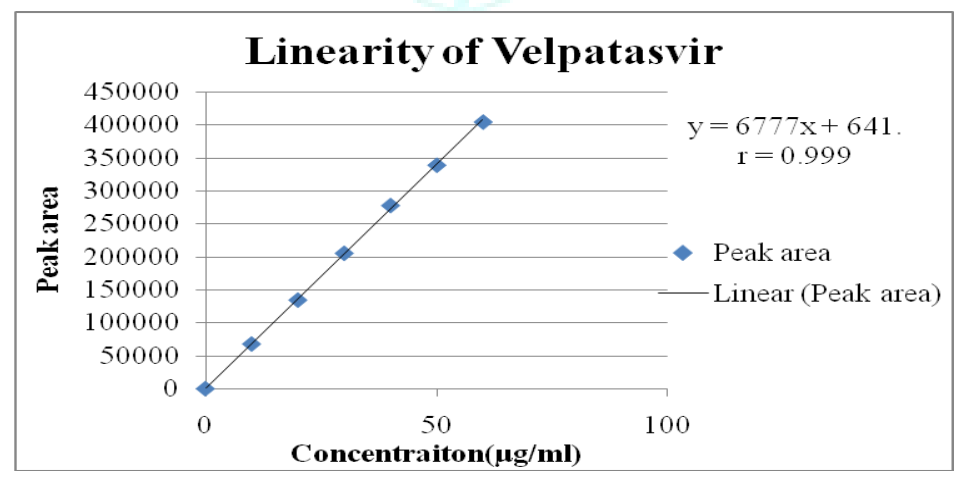

Figure 3: Calibration curve of Velpatasvir in the range 10 to $60 \mu \mathrm{g} / \mathrm{ml}$.

Table 1: Calibration curve of Sofosbuvir and Velpatasvir

\begin{tabular}{|l|l|l|l|l|l|l|}
\hline \multirow{2}{*}{ S.No } & \multicolumn{3}{|c|}{ Sofosbuvir } & \multicolumn{4}{c|}{ Velpatasvir } \\
\cline { 2 - 7 } & Conc( $\mu \mathrm{g} / \mathbf{m l})$ & Rt(mins) & Area & Conc( $\mu \mathrm{g} / \mathbf{m l})$ & Rt(mins) & Area \\
\hline 1 & 40 & 2.405 & 390764 & 10 & 2.987 & 119279 \\
\hline 2 & 80 & 2.406 & 786093 & 20 & 2.982 & 235126 \\
\hline 3 & 120 & 2.402 & 1174300 & 30 & 2.978 & 349782 \\
\hline 4 & 160 & 2.401 & 1563383 & 40 & 2.964 & 467871 \\
\hline 5 & 200 & 2.407 & 1907925 & 50 & 2.992 & 574112 \\
\hline 6 & 240 & 2.409 & 2341934 & 60 & 2.995 & 692155 \\
\hline
\end{tabular}


The accuracy data, method precision data, intermediate precision data for day and intermediate precision data relating to change of instrument are shown in Table 2, Table 3 , table 4 , and Table 5 respectively. Robustness data relating to change in flow rate and robustness data relating to change in mobile phase composition are shown in Table 6 and Table 7 respectively. Results of analysis of laboratory samples are shown in Table 8. Table 9 shows system suitability parameters.

Table 2: Accuracy data

\begin{tabular}{|l|l|l|l|l|l|l|l|}
\hline S.No & & \multicolumn{3}{|c|}{ Sofosbuvir } & \multicolumn{3}{c|}{ Velpatasvir } \\
\cline { 2 - 8 } & $\begin{array}{l}\text { Spiked } \\
\text { level }\end{array}$ & $\begin{array}{l}\text { Amount } \\
\text { added } \\
(\mu \mathrm{g} / \mathrm{ml})\end{array}$ & $\begin{array}{l}\text { Amount } \\
\text { present } \\
(\mu \mathrm{g} / \mathrm{ml})\end{array}$ & $\begin{array}{l}\text { Average } \\
\% \text { Recovery* } \\
\pm \% R S D\end{array}$ & $\begin{array}{l}\text { Amount } \\
\text { added } \\
(\mu \mathrm{g} / \mathrm{ml})\end{array}$ & $\begin{array}{l}\text { Amount } \\
\text { present } \\
(\mu \mathrm{g} / \mathrm{ml})\end{array}$ & $\begin{array}{l}\text { Average } \\
\% \text { Recovery* } \\
\pm \% R S D\end{array}$ \\
\hline $1(\mathrm{n}=6)$ & $50 \%$ & 40.00 & 40.95 & $98.97 \pm 0.43$ & 10.00 & 10.04 & $100.07 \pm 0.46$ \\
\hline $2(\mathrm{n}=6)$ & $100 \%$ & 80.00 & 80.03 & $100.34 \pm 0.28$ & 20.00 & 20.96 & $99.56 \pm 0.55$ \\
\hline $3(\mathrm{n}=6)$ & $150 \%$ & 120.00 & 119.06 & $100.42 \pm 0.40$ & 30.00 & 29.97 & $99.98 \pm 0.59$ \\
\hline
\end{tabular}

${ }^{*} n=6$ (Average of 6 determinations)

Table 3: Method Precision data of Sofosbuvir and Velpatasvir

\begin{tabular}{|l|l|l|l|l|l|l|}
\hline \multirow{2}{*}{ S.No } & \multicolumn{3}{|c|}{ Sofosbuvir } & \multicolumn{3}{c|}{ Velpatasvir } \\
\cline { 2 - 7 } & Conc( $\boldsymbol{\mu g} / \mathbf{m l})$ & Rt(mins) & Area & Conc( $\boldsymbol{\mu g} / \mathbf{m l})$ & Rt(mins) & Area \\
\hline 1 & 160 & 2.403 & 1562412 & 40 & 2.982 & 272468 \\
\hline 2 & 160 & 2.405 & 1565061 & 40 & 2.989 & 277211 \\
\hline 3 & 160 & 2.405 & 1568363 & 40 & 2.987 & 271649 \\
\hline 4 & 160 & 2.406 & 1566157 & 40 & 2.989 & 270677 \\
\hline 5 & 160 & 2.408 & 1566158 & 40 & 2.991 & 273575 \\
\hline 6 & 160 & 2.401 & 1561519 & 40 & 2.974 & 272713 \\
\hline Mean & & & 1564945 & & & 273049 \\
\hline Std.dev & & 2560.9 & & & 2264.3 \\
\hline \%RSD & & 0.2 & & & 0.8 \\
\hline
\end{tabular}

Table 4: Intermediate Precision data relating to change of day

\begin{tabular}{|c|c|c|c|c|c|c|}
\hline \multirow[t]{4}{*}{ S.No } & \multicolumn{6}{|c|}{ Inter-day precision } \\
\hline & \multicolumn{3}{|c|}{ Sofosbuvir } & \multicolumn{3}{|c|}{ Velpatasvir } \\
\hline & \multicolumn{3}{|c|}{ Peak area } & \multicolumn{3}{|c|}{ Peak area } \\
\hline & Conc $(\mu \mathrm{g} / \mathrm{ml})$ & Day-1 & Day-2 & Conc $(\mu \mathrm{g} / \mathrm{ml})$ & Day-1 & Day-2 \\
\hline 1 & 160 & 1566934 & 1569202 & 40 & 275638 & 275929 \\
\hline 2 & 160 & 1567283 & 1560292 & 40 & 272833 & 274633 \\
\hline 3 & 160 & 1569474 & 1563848 & 40 & 279383 & 274182 \\
\hline 4 & 160 & 1565849 & 1564122 & 40 & 271132 & 272901 \\
\hline 5 & 160 & 1563938 & 1565393 & 40 & 270293 & 270322 \\
\hline 6 & 160 & 1562384 & 1563033 & 40 & 274842 & 273932 \\
\hline Mean & & 1565977 & 1564315 & & 274020.2 & 273649.8 \\
\hline SD & & 2527.214 & 2936.945 & & 3337.527 & 1905.742 \\
\hline \%RSD & & 0.16 & 0.18 & & 1.21 & 0.69 \\
\hline
\end{tabular}


Table 5: Intermediate Precision data relating to change of instrument

\begin{tabular}{|c|c|c|c|c|c|c|}
\hline \multirow[t]{4}{*}{ S.No } & \multicolumn{6}{|c|}{ Instrument to Instrument } \\
\hline & \multicolumn{3}{|c|}{ Sofosbuvir } & \multicolumn{3}{|c|}{ Velpatasvir } \\
\hline & & Peak area & & & Peak area & \\
\hline & Conc $(\mu \mathrm{g} / \mathrm{ml})$ & Day-1 & Day-2 & Conc $(\mu \mathrm{g} / \mathrm{ml})$ & Day-1 & Day-2 \\
\hline 1 & 160 & 1564847 & 1564283 & 40 & 276282 & 273832 \\
\hline 2 & 160 & 1565838 & 1568822 & 40 & 272837 & 272922 \\
\hline 3 & 160 & 1561934 & 1562838 & 40 & 277927 & 271973 \\
\hline 4 & 160 & 1562931 & 1563848 & 40 & 271983 & 270283 \\
\hline 5 & 160 & 1562482 & 1561344 & 40 & 277282 & 272833 \\
\hline 6 & 160 & 1563013 & 1563939 & 40 & 270484 & 275752 \\
\hline Mean & & 1563508 & 1564179 & & 274465.8 & 272932.5 \\
\hline Std.dev & & 1505.319 & 2512.804 & & 3094.559 & 1828.069 \\
\hline \%RSD & & 0.09 & 0.16 & & 1.12 & 0.66 \\
\hline
\end{tabular}

Table 6: Robustness data relating to change in flow rate $(1.0 \mathrm{ml} / \mathrm{min})$

\begin{tabular}{|l|l|l|l|l|l|l|l|}
\hline \multirow{2}{*}{ S.No } & & \multicolumn{3}{|c|}{ Sofosbuvir } & \multicolumn{3}{c|}{ Velpatasvir } \\
\cline { 2 - 8 } & $\begin{array}{l}\text { Flow rate } \\
\text { (ml/min) }\end{array}$ & $\begin{array}{l}\text { Average } \\
\text { Peak Area* }\end{array}$ & Std.dev & \%RSD & $\begin{array}{l}\text { Average } \\
\text { Peak Area* }\end{array}$ & Std.dev & \%RSD \\
\hline 1 & $0.9 \mathrm{ml} / \mathrm{min}$ & 1566364 & 1453 & 0.36 & 276606 & 3411 & 0.73 \\
\hline 2 & $1.0 \mathrm{ml} / \mathrm{min}$ & 1566108 & 1087 & 0.27 & 278575 & 1400 & 0.30 \\
\hline 3 & $1.1 \mathrm{ml} / \mathrm{min}$ & 1566214 & 1233 & 0.30 & 276866 & 2723 & 0.58 \\
\hline
\end{tabular}

$*_{n}=3$ (Average of 3 determinations)

Table 7: Robustness data relating to change in mobile phase composition

\begin{tabular}{|l|l|l|l|l|l|l|l|}
\hline \multirow{2}{*}{ S.No } & \multicolumn{3}{|c|}{ Sofosbuvir } & \multicolumn{3}{c|}{ Velpatasvir } \\
\cline { 2 - 9 } & Mobile phase variation (\%) & $\begin{array}{l}\text { Average } \\
\text { peak } \\
\text { area* }\end{array}$ & Std.dev & \%RSD & $\begin{array}{l}\text { Average } \\
\text { peak } \\
\text { area* }\end{array}$ & Std.dev & \%RSD \\
\hline 1 & M.P-1-(BUFFER:ACN::69:31) & 1566072 & 3048 & 0.75 & 277789 & 1720 & 0.37 \\
\hline 2 & M.P-2-(BUFFER:ACN::70:30) & 1566995 & 1237 & 0.30 & 277045 & 1356 & 0.29 \\
\hline 3 & M.P-3-(BUFFER:ACN::71:29) & 1566451 & 1751 & 0.43 & 277058 & 3622 & 0.78 \\
\hline
\end{tabular}

${ }^{*} \mathrm{n}=3$ (Average of 3 determinations)

Table 8: Results of analysis of laboratory samples (Assay)

\begin{tabular}{|l|l|l|l|l|l|l|}
\hline S.No & & & \multicolumn{2}{|c|}{ Sofosbuvir } & \multicolumn{2}{|c|}{ Velpatasvir } \\
\cline { 2 - 7 } & Sample & Label & $\begin{array}{l}\text { Amount } \\
\text { found }\end{array}$ & $\begin{array}{l}\text { \%Purity } \\
\pm \text { RSD }^{*}\end{array}$ & $\begin{array}{l}\text { Amount } \\
\text { found }\end{array}$ & $\begin{array}{l}\text { \%Purity } \\
\pm \text { RSD }^{*}\end{array}$ \\
\hline 1 & $\begin{array}{l}\text { Brand-1 } \\
\text { (VELPANAT) }\end{array}$ & $400 \mathrm{mg} / 100 \mathrm{mg}$ & 399.99 & $99.48 \pm 0.30$ & 99.96 & $99.25 \pm 0.73$ \\
\hline
\end{tabular}

${ }^{*} \mathrm{n}=3$ (Average of 3 determinations) 
Table 9: System suitability parameters

\begin{tabular}{|l|l|l|}
\hline \multirow{2}{*}{ Validation parameter } & \multicolumn{2}{|c|}{ Results } \\
\cline { 2 - 3 } & \multicolumn{1}{|c|}{ Sofosbuvir } & \multicolumn{1}{|c}{ Velpatasvir } \\
\hline Linearity range $(\mu \mathrm{g} / \mathrm{ml})$ & $40-240$ & $\mathrm{y}=6777 \mathrm{x}+641$ \\
\hline Regression equation & $\mathrm{y}=9676 \mathrm{x}+5191$ & 0.9999 \\
\hline Correlation Coefficient(r) & 0.9994 & $98.94 \%$ to $100.58 \%$ \\
\hline Accuracy & $98.58 \%$ to $100.71 \%$ & 0.80 \\
\hline Precision (\%RSD) & 0.20 & \\
\hline Robustness (\%RSD) & & NMT 0.73 \\
\hline $\begin{array}{l}\text { Flow rate: } \\
(1.0 \mathrm{ml} / \mathrm{min} \& 1.2 \mathrm{ml} / \mathrm{min})\end{array}$ & NMT 0.36 & NMT 0.78 \\
\hline $\begin{array}{l}\text { Mobile phase: } \\
\text { Buffer : ACN:MeOH(30:60:10) }\end{array}$ & NMT 0.75 & \\
\hline Intermediate Precision (\%RSD) & & NMT 1.21 \\
\hline Interday - (Day 1 \& Day 2) & NMT 0.18 1.12 \\
\hline $\begin{array}{l}\text { Instrument to Instrument } \\
\text { (Inst-1 \& Inst-2) }\end{array}$ & NMT 0.16 & \\
\hline
\end{tabular}

The statistical analysis of data and the drug recovery data showed that the method was simple, rapid, economical, sensitive, precise and accurate. It can thereby easily adopt for routine quality control analysis. The results of this analysis confirmed that the proposed method was suitable for determination of drug in pharmaceutical formulation with virtually no interference of additives. Hence the proposed method can be successfully applied in simultaneous estimation of Sofosbuvir and Velpatasvirin marketed formulation.

\section{CONCLUSION}

The proposed method is rapid, accurate and sensitive. It makes use of fewer amounts of solvents and change of set of conditions requires a short time. This method can be suitably analyzed for the routine analysis of Sofosbuvir and Velpatasvirin bulk and its pharmaceutical dosage forms. It does not suffer from any interference due to common excipients present in pharmaceutical preparation and can be conveniently adopted for quality control analysis.

\section{ACKNOWLEDGEMENTS}

The authors are thankful to Malla Reddy College of Pharmacy, Secunderabad for providing all facilities to complete the work and Natcofor providing the Sofosbuvir and Velpatasvir as gift sample.

\section{REFERENCES}

1. Raj kumar B, Subrahmanyam KV et al. ,a new validated rp-hplc method for the simultaneous determination of simeprevir and sofosbuvir in pharmaceutical dosage form.Indo american journal of pharmaceutical research, 2016; 6(2).

2. Mohan Vikas P, Satyanarayana T, Vinod Kumar D, Mounika E, Sri Latha M, Anusha R, Sathish Y ET AL., development and validation of new rp-hplc method for the determination of sofosbuvir in pure form.2016, 5(5):775-781.

3. Ravikumar Vejendla, C.V.S. Subramanyam, G. Veerabhadram estimation and validation of sofosbuvir in bulk and tablet dosage form by rp-hplc International Journal of Pharmacy Int J Pharm 2016; 6(2):121-127

4. Sahoo CK, Sudhakar M, Ramana DV, Satyanarayana K, Panda KC. Validation of Analytical Procedures- A Review. Asian J. Pharm. Ana. 2018; 8(2):109-116.

5. ICH validation of Analytical procedures: Text and Methodology Q2 (R1) in proceedings of International Conference on Harmonization. Geneva: Switzerland. 2005. 205-210.

6. ICH guidelines, Validation of Analytical procedures technical requirements for registration of Pharmaceuticals for Human use Text and Methodology Q2 (R1). International Conference on Harmonization. Geneva: Switzerland. 2005.325-340p. 